\title{
Quality Evaluation of the Physical Properties and Phytochemicals of Selected Date Palm New Strain Grown under Nag Hamady Conditions
}

\section{Rasha N. Arafa ${ }^{1 *}$, Sayed A. A. Elsayh ${ }^{2}$, Ghada A. Ali ${ }^{1}$, Rabab W. El Aramany $^{1}$ and E. H. El-Bassel ${ }^{2}$}

${ }^{1}$ Central Lab of Date Palm Researches and Development, Agriculture Research Center, Giza, Egypt

${ }^{2}$ Fruit Breeding Department, Horticulture Research Institute, Agriculture Research Center, Giza, Egypt

*Corresponding Author: Rasha N. Arafa, Central Lab of Date Palm Researches and Development, Agriculture Research Center, Giza, Egypt.

E-mail: rashanagyarafa@gmail.com

DOI: $10.31080 /$ ASNH.2022.06.1008
Received: December 28, 2021

Published: February 17, 2022

(C) All rights are reserved by Rasha N. Arafa., et al.

\section{Abstract}

It is considered that the date palm fruit (Phoenix dactylifera) was one of the first crops to be farmed in the Middle East, dating back thousands of years. The current study aimed to assess the variations in the quality of the new strain of Nag Hamady and Medjool cultivar on the basis of physical characteristics and chemicals properties. There was conducting research on date palm fruits from a 30 -year-old seedling tree in Nag Hamady, Egypt. The results were compared to those of Medjool cv. in two consecutive seasons (2020 and 2021). A novel seedling strain's physical and chemical properties were the primary focus of this investigation. In compared the number of date $/ \mathrm{Kg}$, Medjool cv. recorded (110 kg/palm), however the maximum yield was seen in Nag Hamady 2 (250 kg/palm). When it comes to physical features like length, diameter, weight, and number of dates per kg, the Nag Hamady 2 had the greatest numbers, at $5.40 \mathrm{~cm}, 2.60 \mathrm{~cm}, 28.00 \mathrm{~g}$, and 38.00 dates per $\mathrm{kg}$, while the Medjool had the lowest. Nag Hamady 2 has the best chemical characteristics, according to the results. The soluble solid content of a date palm fruit is 80.00 gm per 100 gm. There were 80.20 gm of carbs per $100 \mathrm{gm}$ and $3.85 \mathrm{gm}$ of protein per $100 \mathrm{gm}$. It was determined that the ash and fiber levels were 0.67 and $6.50 \mathrm{gm}$ per $100 \mathrm{gm}$, respectively. The carbohydrate content was found to be high in glucose and fructose, and it was found to be free of sucrose. Due to its low level of crude lipids $0.50 \mathrm{~g} / 100 \mathrm{~g}$ compared with content of sugar, date palm might be beneficial for cardiovascular and diabetic patients. There is the great calcium content in Nag Hamady 2 may be a good supply of calcium, which is required for healthy bone formation and energy metabolism. The date fruits are regarded to be a healthy diet rich in minerals and play an important function in the development of the immune system for humans because of the presence of these key components in the fruit.

Key words: Date Palm; Chemical and Physical Properties; Carbohydrate; Minerals and Sugars

\section{Introduction}

The date palm is one of the most ancient fruit crops of the North Africa, Arabian Peninsula, and the Middle East, also it is cultivated in other parts of the world. They are regarded as a significant source of revenue as well as a staple meal for the local people in the nations where they are grown. The dates include pectin, dietary fiber, tannins, certain vitamins and minerals, minor amounts of organic acids, and a variety of antioxidant anti-mutagenic substances. Date fruit as a whole has a wide variety of uses due to its nutritious characteristics [1]. The epidermal studies having previously proven that there are obvious substantial beneficial connections between fruit and vegetable consumption and lower rates of heart attack mortality, common malignancies, and other progressive illnesses, as well as senility [2]. This is because these foods 
might deliver an ideal combination of soluble fiber, natural antioxidants, and other biotic substances. Dates contain some nutrients in abundance that provide a powerful source of quick energy (314 calories) due to their high carbohydrate content (70-80\%). The majority of carbohydrates in dates were reducing sugars (glucose and fructose), which are easily absorbed by the body [3]. The dates have a small protein concentration $(2.5-6.5 \mathrm{~g} / 100 \mathrm{~g})$ and include 23 different kinds of amino acids, many of which are not found in important fruit like oranges, apples, and bananas. Dates were also a rich source of minerals including, potassium, iron and iodine.

The soft dates as (Zagloul, Hayani, Samani, Amhat and Bent Aicha), semi-dry dates as (Saidy and Al-Amri), and dry dates (Saidy and Al-Amri) have been grown in Egypt's Nile River valley, oases, and deserts (Barakawi, Ebrimi and Sakouti). Furthermore, as a consequence of sexual production, there are a large numerous of seedling date palms; several of them are particularly desired for fruit characteristics and proliferation of their offshoots [4]. Understanding certain significant physical qualities such as the dimensions of various fruits/vegetables/grains, bulk density, actual density and porosity is critical for the design of storage structures, processing equipment and procedures [5]. When describing agricultural products, size and form are the most used terms. There are several factors to consider when deciding how many fruits may fit in a particular shipping container or plastic bag, including the fruit's physical measurements. Variations in the density of fruits and vegetables may frequently be used to discern quality differences [6]. The novel strain's physical parameters (height, diameter, height/ diameter, surface area, and fleshy thickness) and seed dimensions have been determined. Acidity, total carbs, total sugars, reducing sugars, energy value calculation, total phenolic, amino acids, tannins, and mineral content were all measured. The data acquired from the novel strain Nag Hamady 2 was compared to that of a recognized cultivar common as Medjool. The authors of the study objective intended to assess the physicochemical characteristics of a newly discovered strain in Nag Hamady, Qena governorate, in accordance with international date specifications.

\section{Materials and Methods}

This research was conducted in Nag Hamady in two consecutive seasons, 2020 and 2021, to assess a novel strain (unidentified) of date palm fruits called Nag Hamady 2 that was cultivated in Nag Hamady, Qena governorate, Egypt. The palm grew to a length of 10$12 \mathrm{~m}$, with a trunk diameter of around $1.70 \mathrm{~m}$, there were 60 leaves per palm, a leaf height of $2.85 \mathrm{~m}$, and 15 fruit bunches per palm, as shown in figure 1.

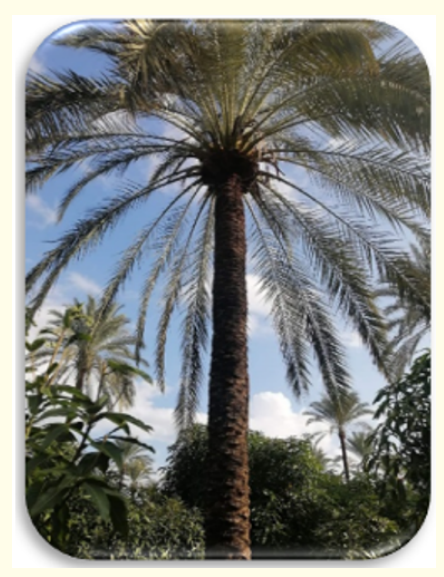

Figure 1: The date palm tree unknown in Nag Hamady Government.

The productivity of this date palm has been $250 \mathrm{~kg} / \mathrm{palm}$. This palm has not yet given any offshoots. This is palm was planted on poor soil that had not been fertilized or irrigated. All data of Medjool was compared to dates from the Nag Hamady 2 palm, which was cultivated in the Qena governorate.

\section{Collection and processing of samples}

At the Tamr maturity stage, sixty fruits were randomly picked healthy and free of damage for each sample and sent to the laboratory for examination. All analyses were conducted at the Central Laboratory for Date Palm Research and Development at the Agriculture Research Center in Giza, Egypt, and at the Chemistry of Natural and Microbial Products Department of the Pharmaceutical Industry Division at the National Research Center in Dokki, Giza, Egypt. We evaluated the physical and chemical properties of this palm and compared them to Medjool cv., as figure 2 and 3.

The fruits were separated into two groups: the first was freshly and used to assess certain physical features; the second group was drying for 48 hours at $70{ }^{\circ} \mathrm{C}$ to remove a moisture and then finally grinded using a blender to determine chemical attributes. After removing the pits with a sharp knife edge, the flesh of date was washed and chopped into tiny segments shortly before to examination. 


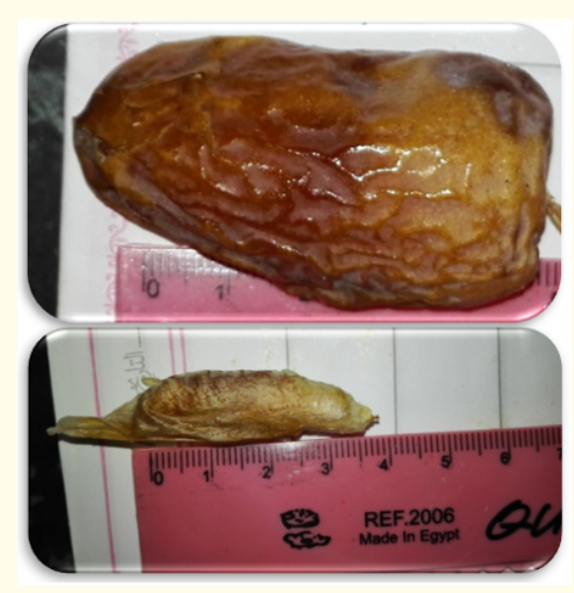

Figure 2: Collection of novel strain of date palm fruits, Nag Hamady 2.

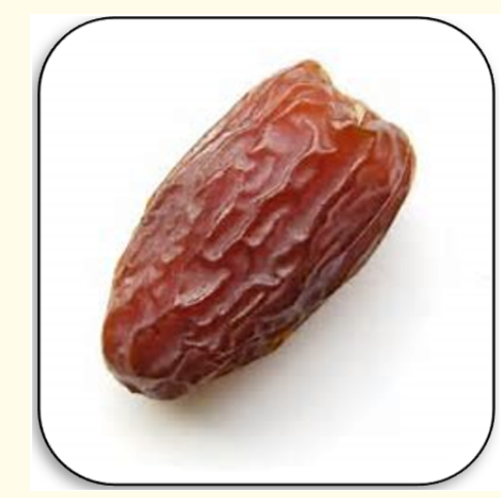

Figure 3: Date palm fruits of Medjool cultivar.

\section{Physical description}

The measurements of the fruits (length; diameter; and flesh thickness), as well as the seed length, were determined in centimeters using a Digital caliper. The average weight of fruits and seeds in grams and the numerous of fruits per kilograms were calculated using an electronic balance [7]. The volume of the fruit $\left(\mathrm{cm}^{3}\right)$ was estimated using the water displacement technique, and the fruit density was computed as the weight of the fruit divided by the volume.

\section{Chemical characteristics}

To evaluate the fruit juice's total soluble solids (TSS), a handheld refracto-meter was used; Proximate analysis (ash content, crude fiber, total protein, lipid and moisture content) of date fruits were carried out in accordance to the standard analytical procedure for food analysis, as reported by [8]. According to [9], the fruit acidity has been measured.

The total and reducing sugar content in different varieties of date fruits were analyzed according to the standard procedure reported by [10]. The differential among both total sugars and reducing sugars was used to compute non-reducing sugars. Using the [11] formula, we calculated the enthalpy values of dates. Utilizing the method outlined in [12], the total phenolic content of palm date fruits was determined. Laurey [13] method of amino acid analysis was followed. The [14] technique was used to measure the amount of condensed tannins in the sample. The mineral contents, namely potassium (K), phosphorus (P), magnesium (Mg), calcium (Ca), sodium $(\mathrm{Na})$, and iron ( $\mathrm{Fe})$, in the date samples were determined as reported by [15].

The relative distribution of essential amino acids present in the date fruits was measured by oxidation followed by hydrolysis using hydrogen peroxide/formic acid/phenol and 6M hydrogen peroxide solution, respectively, as described by [16]. The amino acids were then separated and analyzed by ion-exchange chromatography and photometric detection (440 and $570 \mathrm{~nm}$ ) using ninhydrin reagent, respectively.

\section{Analytical statistics}

A two-way analysis of variance (ANOVA) was performed using MSTATC software according to [17].

\section{Results and Discussions}

\section{Physical properties}

\section{Date fruit dimensions}

In the process of sorting and rating the date palm fruits, suppliers typically apply the criteria provided by physical values. The physical characteristics of dates, such as their flesh weight, seed weight, length and diameter, were found to change considerably from one variety to the next, according to [18]. The dates of Nag Hamady 2 were analyzed as in table 1, the optimum fruits dimensions were observed compared to Medjool cv. at the Tamr phase. The average length of date, diameter of fruits, and length/diameter rate were all within the range of results according to [19].

Date palm cultivars investigated by [20] showed substantial differences in fruit length, with the cultivars Zaghloul, Kuboshy and 
Samany reporting the longest fruits, respectively, with the cultivar Samany registering the shortest. On the other hands, the Ajwa variety showed the most significant variation in the dimension parameter among the dates studied. These dates were smaller and shorter in length than any other variety. The diameter and length of this variety were $14.6 \mathrm{~mm}$ and $26.4 \mathrm{~mm}$, respectively. It was discovered that the Anbara dates were the longest of all the nine samples tested [21].

\section{Weight of the fruits}

As demonstrated in table 1, the averaged fruit weight, fruit volume, and seeds weight of Nag Hamady 2 were greater than those of Medjool cv. The fruits weight and length, flesh thickness, and weight of seed all play a role in differentiating cultivars. The date seed accounts for between 11 and 18 (\%) weight of the date fruit [22]. Samia [23] discovered that the fruit weights could be classified as follows: Sewy (13.27g), Khalas (11.65g), and Zahdi (11.24g), followed by fruits of the "Sakai" cultivar that were the lightest in weight (7.42g). There was no significant variation in seed volume between the Sogaai and Anbara, which weighed 16.8 and $16.5 \mathrm{gm}$ [21]. The largest dates (28.1 and $24.38 \mathrm{gm}$ ) and the greatest pulp weight ( 27.1 and $23.13 \mathrm{gm}$ ) of the two seasons were produced by the Madjool cultivar in the first season. It was the Sewy cultivar date that had the largest seed weight (2.0 and $1.84 \mathrm{gm}$ ) and the lowest pulp percentage $(0.02 \%)$. In the diameter and length measurements, Anbara cultivar had the longest and virtually largest date size among the cultivars tested. When it came to physical fruit qualities, Anbara was the best cultivar at the time [24].

\section{Yield of palm trees}

When the fruits reached the tamr stage, the following information was recorded: The number of bunches per palm and the yield/ palm (kg) statistics shown in table 1 demonstrate the same pattern as the number of bunches/palm, i.e. palms of Nag Hamady 2 generated the maximum output of $250 \mathrm{~kg} / \mathrm{palm}$ on average, followed by Medjool at around $110 \mathrm{~kg} / \mathrm{palm}$. These findings are consistent with the findings by [25] who noted that there were large and significant variances in the fruiting pattern of many of date palms. Osman [26] observation that the average fruit production of Samany date palms cultivated in El-Badrasheen is $165 \mathrm{~kg}$. Whereas the Kom-Ambo crop in Aswan yielded $145 \mathrm{~kg}$. In a similar vein, [24] reported that during the first season, the number of annually developed bunches/palm generated by Madjool and Khadari cultivars was between 9.5 and 10.33 bunches/palm. During the second season, Ajwa and Khadari cultivars produced 9.7 and 10.2 bunches/ palm. Also, throughout the two seasons, the local semi-dry cultivar Anbara achieved the maximum fruit yield weight (kg). The Ajwa cultivar produced the lowest overall yield.

\begin{tabular}{|l|c|c|c|}
\hline $\begin{array}{l}\text { Physical } \\
\text { properties }\end{array}$ & Nag Hamady 2 & Medjool & $\begin{array}{c}\text { Signifi- } \\
\text { cantly }\end{array}$ \\
\hline Fruit weight & $28.00 \mathrm{~g}$ & $22.16 \mathrm{~g}$ & $\mathrm{~S}$ \\
\hline Fruit length & $5.40 \mathrm{~cm}$ & $4.50 \mathrm{~cm}$ & $\mathrm{~S}$ \\
\hline Fruit diameter & $2.60 \mathrm{~cm}$ & $2.43 \mathrm{~cm}$ & $\mathrm{~S}$ \\
\hline Fruit volume & $24.87 \mathrm{~cm}^{3}$ & $20.26 \mathrm{~cm}^{3}$ & $\mathrm{~S}$ \\
\hline Flesh thickness & $0.79 \mathrm{~cm}^{3}$ & $0.88 \mathrm{~cm}^{-}$ & $\mathrm{S}$ \\
\hline Seed weight & $1.78 \mathrm{~g}$ & $1.34 \mathrm{~g}$ & $\mathrm{~S}$ \\
\hline Seed length & $4.45 \mathrm{~cm}$ & $2.57 \mathrm{~cm}$ & $\mathrm{~S}$ \\
\hline Palm yield & $250 \mathrm{Kg} / \mathrm{palm}$ & $110 \mathrm{Kg} / \mathrm{palm}$ & $\mathrm{S}$ \\
\hline Number of date/Kg & $38.00 \mathrm{dates}$ & $45.00 \mathrm{dates}$ & $\mathrm{S}$ \\
\hline $\begin{array}{l}\text { Number of fruit } \\
\text { bunches }\end{array}$ & 14 & 12 & $\mathrm{NS}$ \\
\hline
\end{tabular}

Table 1: Physical properties of Nag Hamady 2 and Medjool dates fruits.

\section{Numerous of dates $/ \mathrm{kg}$}

The quantity of fruits per kilogram varied between 33 and 41 in Nag Hamady 2 and Medjool cv. [27] observed that a raise in fruits number $/ \mathrm{kg}$ at the Semi-Rutab and Rutab stages, which ranged between 36 - 92 and 40 - 98, respectively. Gado [28] stated that the amount of fruits per kilogram varied between (40 - 72).

Fruit bunches per palm numerous

The data in table 1 reveal that there is no statistically significant difference in the numerous of bunches/palm. These findings are consistent with [23], who found that Sewy, Medjool, and Zahdi palms yielded the most bunches (11.84, 11.33, and 10.84 bunch/ palm, respectively), with no considerable variation amongst them. However, Khalas generated the most bunches ( 9.00 bunches/palm) in compared to Sakai palms, which provided the fewest bunches (6.67 bunches/palm). Alahyane., et al. [29] cleared that, the varieties, growing circumstances, ripening, growth season, geographic origin, agricultural administration, and storage conditions, among other factors, might be to blame for these variances in date fruit measurements. 


\section{Chemical property}

Dates contain a high carbohydrate content, 14 different types of fatty acids, 15 salts and minerals, 23 different amino acids and proteins, six vitamins, and a high nutritious fiber content, as shown in figure $4[30]$.

Processing, preservation, and storage of the date palm fruit requires an understanding of the fruit's chemical qualities, such as its moisture, ash, protein, lipid and fiber content as reported by [31]. Traditional usage of date palm fruits in treat various illnesses, such as to alleviate a throat infection and to alleviate fever, has long been practiced. Evidence of date palm fruit's health advantages has been based on experimental evidence that has shown that date palm fruits may block or suppress various illnesses. As far as therapeutic properties go, date palm fruits have been shown to include antioxidant, anti-inflammatory, and anti-cancer properties [32]. Previous research has shown that the biological activities of date palm fruits vary depending on the kind of variation.

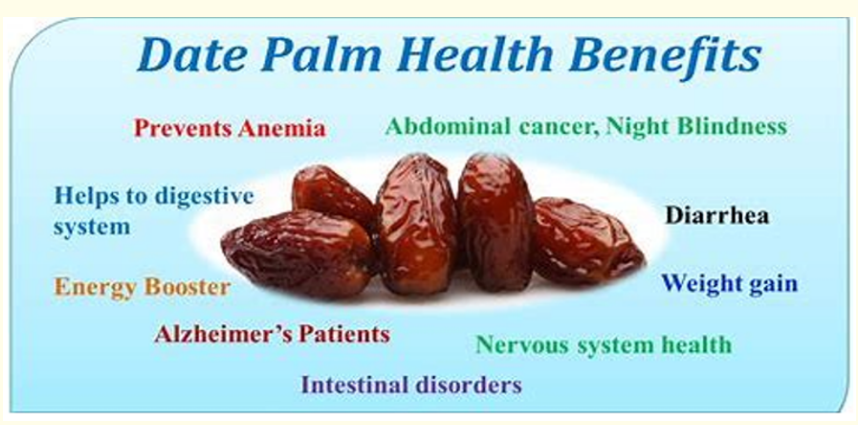

Figure 4: The health benefits of a date palm fruits.

\section{The moisture}

The moisture content in food items is regarded as a significant factor in preventing food spoiling and hence influences customer preferences. Moisture is an important component of fruit that impacts its quality and functions as a preservative. As demonstrated in table 2, the moisture content of Nag Hamady 2 date fruits was $19.0 \%$ and that of Medjool was $23.40 \%$ in the current research. Dates are considered soft if they have a moisture content of much more than $30 \%$, dry if the level is less than $10 \%$, and half soft if the rate is between $10 \%$ and $30 \%$. Using this terminology, we may describe the Nag Hamady 2 and Medjool dates as half soft dates [33]. Our findings are consistent with those of [10], who said that humidity levels varied between 20.25 to $22.14 \%$, with Khalas having the greatest moisture content and Boumaan having the lowest. According to [34], the moisture content of several Arabian and local date cultivars' fruits varied from 21.45 to $32.90 \%$ depending on cultivar.

Rastegar., et al. [35] cleared that the moisture level of the dates decreased throughout the Rutab stage, making them non-perishable and able to be stored for a longer amount of time while also being resistant to microbiological assault from yeast and mold. Climate factors, harvesting season, and drying conditions all influence moisture content. The Ajwa dates had the greatest moisture level, $28.6 \%$, while the Berni dates had the least moisture levels, $12.6 \%$. The low moisture content means a longer shelf life, but it also results in the formation of dry dates, which are less liked by customers. According to [23], the average values of the two seasons suggest that the moisture content of meat was the highest in "Sakai" fruits (32.59\%), followed by Medjool (28.85\%), Zahdi (26.04\%), and Sewy (26.04\%). According to the findings of a research of 11 various varieties of date fruits grown in the UAE, Maktoomi and Khalas had the lowest (13.6\%) and maximum (20.5\%) moisture levels, respectively [36].

Total soluble solids (T.S.S)

T.S.S is the main quality factors effecting taste and flavor. The data in table 2 show that there are considerable variations in TSS levels in the fruits, with Nag Hamady 2 registering the greatest rate of $80.00 \mathrm{~g} / 100 \mathrm{~g}$ and Medjool cv. recording 65.22g/100g. El-Sohaimy and Hafez [37] determined the TSS content of Trunja, Lagou, and Gounda dates to be $86.20 \%, 85.9 \%$, and $86.8 \%$, respectively, in earlier investigations. Amen., et al. [38] computed TSS as 70.84, $68.86,67.94$, and $64.49 \%$ as an averaged of the three analyzed seasons for fruits from Aswan, El-Kharga, Al-Dakhla, and Assiut, respectively. Samia [23] observed in Sakai fruits that the average T.S.S. percentage was (71.35\%) compared to (50.30\%) for Zahdi cv. The other examined cvs., including Sewy cv., exhibited intermediate T.S.S. percentage. Nevertheless, [26] discovered that Zaghloul and Samani cultivars cultivated in Kom-Ambo had the greatest TSS value $(31.32 \%)$, while those produced in El-Badrashen had the lowest TSS (26.30\%).

\section{Content of ash}

The ash percentage of foods serves as a proxy for their nutritional value. The ash concentration of Nag Hamady 2 and Medjool 
was 1.20 and $1.63(\mathrm{~g} / 100 \mathrm{~g})$, respectively, as reported in table 2. According to prior evaluations, the average proportion of ash Ambrah had a content of $1.67 \%$, whereas Sagai had a content of $1.14 \%$. The ash rate of the date types investigated ranges between 1.23 and $1.23 \%$ for Hammouri and Deglet Nour types, respectively [39]. Shishi and Fard recorded the lowest (1.37\%) and highest (1.97\%) ash levels, respectively. On the other hand. The ash content varied from around $5.23 \%$ for Ajwa to about $6.20 \%$ for Berni [21].

\section{Fiber content in crude form}

Healthy diets nowadays include consuming foods that are low in salt, fat, cholesterol, and rich in fiber. The crude fiber content of date fruit Nag Hamady 2 approximately 6.50g/100g and $6.86 \mathrm{~g} / 100 \mathrm{~g}$ when combined with Medjool. Elsohaimy and Hafez [37] found the greatest value of crude fiber (5.30 to 6.51g/100g) in date palm fruits in prior investigations. According to [40], the total dietary fiber content of date fruit cultivars varied from 6.81 to $11.70 \mathrm{~g} / 100 \mathrm{~g}$ for the varietals Medjool and Hillawi, respectively. According to [31], dates are high in crude fiber, with Trunja, Lagou, and Gounda dates containing 6.9\%, 6.05\%, and 6.5\%, respectively. On the other hand, reported a lower value $(0.50 \mathrm{~g} / 100 \mathrm{~g})$ of crude fiber content than the results observed in this investigation [41].

\section{Protein content in total}

The protein content of dried date fruit approximated $3.85 \mathrm{~g} / 100 \mathrm{~g}$ for Nag Hamady 2, and 1.74g/100g for Medjool cv. These findings were consistent with [42], who stated that date fruit contains 1 $3 \%$ protein and has amino acid structure that really is beneficial to human needs; nonetheless, the levels are too little to be regarded an essential nutritional resource. According to [40], the protein content of date fruit cultivars ranged from 1.88 to $2.77 \%$. On the contrary hand, the date palm fruit has a greater protein level of 2.3 - 5.6\%, according to [43]. As far as fruit types go, their protein and lipid content varied from 2.19 to 3.12 and 0.25 to $0.51 \%$ for Jabri, Raziz, and Shiakt, respectively [36]. The dates have a protein content ranging from 2.08 to $3.10 \%$. There are no notable differences between the various strains. In terms of protein content, Ajwa had the greatest value at $3.1 \%$ and the highest value for crude fiber at $3.36 \%[21]$.

\section{Crude lipid}

The consuming date's fruit is considered healthy for persons who suffer from heart and blood problems due to its low fat content comparison to its greater sugar value. It was found in the dried dates of Nag Hammadi strain 2, the fat ratio was $0.23 \mathrm{~g} / 100 \mathrm{~g}$. With Medjool, the concentration was $0.15 \mathrm{~g} / 100 \mathrm{~g}$.

Al-Farsi and Lee [44] found that fresh dates had a fat content of $0.14 \mathrm{~g} / 100 \mathrm{~g}$, whereas dried dates have a fat content of $0.38 \mathrm{~g} / 100 \mathrm{~g}$. Vinita and Darshan [40] observed that the fat content of date fruit cultivars varied from 0.17 to $0.50 \%$. In summary, the modest differences in protein, fat, and ash concentrations were identified for all of the tested date types when compared to moisture content. The diversity in the proximate analysis of distinct date fruit samples might be attributed to geographical variables as well as agro-climatic and environmental circumstances [36].

The acidity

According to the data in table 2, the average content of acidity was between $0.09 \%$ for Nag Hamady 2 and $0.11 \%$ for Medjool. Haseeb [45] demonstrated that the acidity level including all palm trees evaluated showed the equal statistical properties over the study seasons. Metwaly., et al. [46] determined that the intermediate content of acidity in the Sewi cultivar was $0.08 \%$. Salama., et al. [47], on the other hand, discovered that the moderate of fruit total acidity in Hayany date palm planted in Egypt's areas as Ras-Sudr city, South Sinai Region, was contribution varied from 0.22 to 0.32 (\%).

\section{Calculation of total carbohydrates}

According to the data, Nag Hamady 2 dates have a greatest carbohydrate content of $80.20 \mathrm{~g} / 100 \mathrm{~g}$, whereas Medjool has a carbohydrate ratio of $78.33 \mathrm{~g} / 100 \mathrm{~g}$. The carbohydrate was comprises of a largest glucose quantity, fructose (reducing sugar), and a minimal amount of sucrose (non-reducing sugar), which are easy to digest in human cells and beneficial for generating energy for metabolic pathways, whereas dates contain fewer amount of xylose, arabinose, glucuronic acid, and galacturonic acid, as shown in figure 5.

The dates are an excellent source of carbohydrates, which are the primary source of energy for the human body. Due to the belief that dates are mostly made up of sugars, the calories value and sugar content are linked. Because of this, the mob choose dates as their primary food source during the holy month of Ramadan and for those who have worked hard [48].

In the current investigation, Nag Hamady 2 had greater total sugar and reduced sugar levels than Medjool, as demonstrated in 
table 2. The date fruit contains the most vital carbohydrate constituents, making it a great resource for the human body [49]. Dates have a large carbohydrate level ranging from 77.31 to $88.02 \%$ [50] for Tunisian cultivars, with Trunja accounting for $83.95 \%$, Lagou accounting for $77.31 \%$, and Gounda accounting for $84.79 \%$.

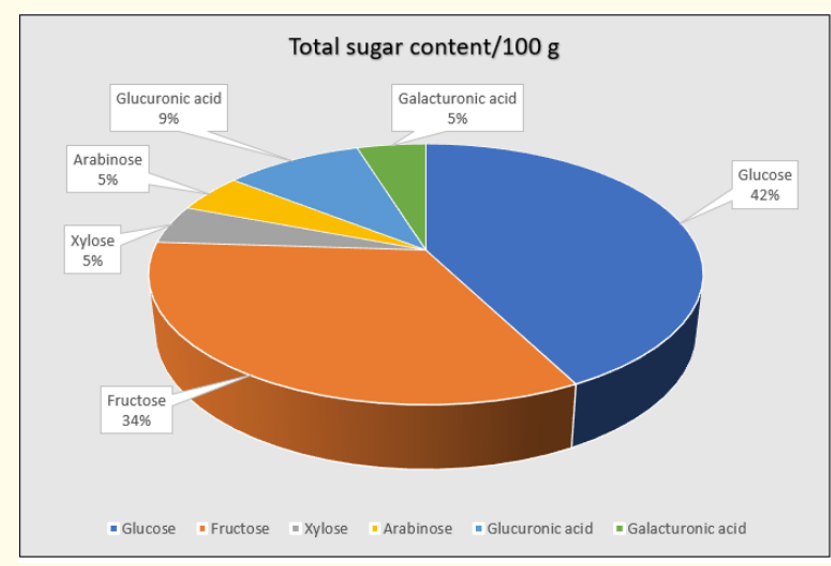

Figure 5: Total sugar content /100g of new strain of Nag Hamady 2.

The current study findings are very identical to those published by [10], who discovered 64.8 to $76.2 \%$ reducing sugar in date fruit. Iqbal., et al. [25] showed somewhat smaller rate for total soluble sugar, reducing sugar, and non-reducing sugar in date fruit (71.05, 56.65 , and $13.87 \mathrm{~g} / 100 \mathrm{~g}$, respectively).

There are a lot of different types of sugar in date fruits, but the most common are glucose and fructose, which are both mono saccharides (sucrose). This study found that Maktoomi dates had a maximum sugar level of $90.5 \%$, whilst Fard dates had the lowest sugar content of $71.8 \%$ [36]. Halaoua had the largest carbohydrate level (78.8\%), while the carbohydrate content in Ajwa was the lowest (56.8\%) [21].

For processing, preservation, storage and grading of the date fruits, the information provided by proximate analysis is essential. To help the pharmaceutical, food and beverage sectors, the sugar assay for the specific types of UAE date fruits would be beneficial. In order to produce a unique, soluble, solid date fruit sugar (fructose and glucose) that is superior to commercially refined sugar (sucrose), quantitative measurement of the sugar components in date fruits is critical [36]. The glucose is easily absorbed through- out digestion and causes a quick rise in blood sugar levels. Because fructose is twice as sweet as glucose, it causes satisfaction and may lower overall calorie consumption when contrasted to fat-rich diets [51]. Amongst the four date fruit types, Khadrawi already had the greatest starch content $(17.46 \mathrm{~g} / 100 \mathrm{~g})$ while Medjool had the fewest (15.96g/100g) [40].

\section{Value of energy}

The energy given by the protein, fat and carbs in dates was estimated. This technique of calculating energy presupposes that every carbohydrate range provides energy. In table 2 demonstrated that the energy value of dried dates of Nag Hamady 2 was greater than Medjool, with practically all of the energy coming from carbs. Bedouin Arabs who consume them on a daily basis have a much decreased incidence of cancer and heart disease.

Dates can provide affordable food and energy for an increasing population in a lot of countries, enhancing food security. Date's high sugar content, according to [44], makes them an excellent source of energy. The energy level of fresh and drying dates is 213 and 314 $\mathrm{kcal} / 100 \mathrm{~g}$ respectively. The sugar in dates are rapidly digested and may instantly be transferred to the blood after consuming and can swiftly be processed to provide energy for numerous cellular processes [37]. From $254 \mathrm{kcal}$ of Ajwa energy content to the maximum of $318 \mathrm{kcal}$ in Halaoua, the total energy was studied and raised. The quantity of dry matter, lipids, and carbs influenced the total energy value. Therefore, the increased energy value identified for Halaoua was owing to the larger levels of fat and carbohydrate that this variety displayed. Findings were generally similar with earlier investigations, albeit with some minor differences. Varieties, production tactics, and environmental variables might all play a role in any variances [52]. It is possible that the invertase activity during ripening has a direct influence on the non-reducing sugars, which account for $95.08 \%$ of total sugars at Tamr stage. The calories value of Saidy date fruits was determined to be (335.21 Cal./100g) [53].

\section{Total phenolic}

Phenolic chemicals have a significant function in disease and insect defense. The fruits date has been shown to contain a variety of phenolic compounds. As demonstrated in table 2, the Medjool cultivar has a much greater total phenol content $(554.00 \mathrm{mg} / 100 \mathrm{~g})$ than the Nag Hamady 2 cultivar, which has a concentration of $145.70 \mathrm{mg} / 100 \mathrm{~g}$ (dry weight). This finding is consistent with the 
findings of [54], who discovered an average of Kharak date (Iranian dry date) at $141.35 \mathrm{mg} / 100 \mathrm{~g}$ dry weight. According to [55], the Tunisian date cultivars have an average amount of total phenolic content (160.98 to $222.23 \mathrm{mg} / 100 \mathrm{~g} \mathrm{FW}$ ). The observed discrepancies might be attributed to a variety of factors, including geographical origin, variety, post - harvest storage circumstances, extraction period, and solvent.

Wu., et al. [56] discovered that Deglet Noor and Medjool cultivars have significant levels of total phenolic content, with 661.0 and $572.0 \mathrm{mg} / 100 \mathrm{~g}$ fresh weight, respectively. Louaileche., et al. [57], indicated that the total phenolic content of eight date types varied from 169.18 to $381.76 \mathrm{mg} \mathrm{GAE} / 100 \mathrm{~g}$ DW. On a dry fruits, the total phenolic content of Saidy date flesh was $297.37 \mathrm{mg}$ as gallic acid/100g [53].

Gallic acid, catechin, ferulic acid, rutin, syringic, and p-coumaric acid are the principal phenolic components present in date fruits [58], making them good antioxidants. In addition, several researches have shown that phenolic chemicals have a protective impact on human health. The intake of polyphenols (flavonoids) has been linked to a lower incidence of chronic illnesses such as cardiovascular disease, diabetes, and cancer in epidemiological studies [59].

Amino acids content

Date fruits Nag Hamady 2 had an amino acid concentration of $1.60 \mathrm{~g} / 100 \mathrm{~g}$, whereas Medjool had a value of $1.15 \mathrm{~g} / 100 \mathrm{~g}$. Because they contain vital amino acids, date fruits are regarded as a significant nutrient source [44]. Date's amino acid concentration decreases as they mature owing to water content reduction [60]. In particular for cell development and regeneration, a variety of amino acids found in dates are necessary for a healthy human metabolism [8]. As a building block for protein and energy control in humans, date fruits help to alleviate malnutrition [61].

The necessary amino acids (glutamine, aspartic acid, glycine, histidine and valine) contained in the date varieties of the United Arab Emirates were analyzed. All date types except Bumaan and Shikat have glutamine as the most abundant amino acid, according to the findings of the study. Among all date varietals, histidine was found in the lowest concentrations [36].

\begin{tabular}{|l|c|c|c|}
\hline Chemical properties & Nag Hamady 2 & Medjool & Significantly \\
\hline Moisture & $19.00 \%$ & $23.40 \%$ & $\mathrm{~S}$ \\
\hline Total soluble solids & $80.00 \mathrm{~g} / 100 \mathrm{~g}$ & $65.22 \mathrm{~g} / 100 \mathrm{~g}$ & $\mathrm{~S}$ \\
\hline Ach content & $1.20 \mathrm{~g} / 100 \mathrm{~g}$ & $1.63 \mathrm{~g} / 100 \mathrm{~g}$ & $\mathrm{~S}$ \\
\hline Crude fiber & $6.50 \mathrm{~g} / 100 \mathrm{~g}$ & $6.86 \mathrm{~g} / 100 \mathrm{~g}$ & $\mathrm{NS}$ \\
\hline Total protein content & $3.85 \mathrm{~g} / 100 \mathrm{~g}$ & $1.74 \mathrm{~g} / 100 \mathrm{~g}$ & $\mathrm{~S}$ \\
\hline Crude lipid & $0.23 \mathrm{~g} / 100 \mathrm{~g}$ & $0.15 \mathrm{~g} / 100 \mathrm{~g}$ & $\mathrm{~S}$ \\
\hline Acidity & $0.09 \%$ & $0.11 \%$ & $\mathrm{NS}$ \\
\hline Total carbohydrates & $80.20 \mathrm{~g} / 100 \mathrm{~g}$ & $78.33 \mathrm{~g} / 100 \mathrm{~g}$ & $\mathrm{~S}$ \\
\hline Total sugar & $76.00 \mathrm{~g} / 100 \mathrm{~g}$ & $66.60 \mathrm{~g} / 100 \mathrm{~g}$ & $\mathrm{~S}$ \\
\hline Reducing sugar & $76.00 \mathrm{~g} / 100 \mathrm{~g}$ & $65.84 \mathrm{~g} / 100 \mathrm{~g}$ & $\mathrm{~S}$ \\
\hline Non reducing sugar & 0.00 & $0.80 \mathrm{~g} / 100 \mathrm{~g}$ & $\mathrm{~S}$ \\
\hline Starch & $0.90 \mathrm{~g} / 100 \mathrm{~g}$ & $0.75 \mathrm{~g} / 100 \mathrm{~g}$ & $\mathrm{~S}$ \\
\hline Energy value & $336.55 \mathrm{Kcal} / 100 \mathrm{~g}$ & $288.00 \mathrm{Kcal} / 100 \mathrm{~g}$ & $\mathrm{~S}$ \\
\hline Total phenolic & $145.70 \mathrm{mg} / 100 \mathrm{~g}$ & $554.00 \mathrm{mg} / 100 \mathrm{~g}$ & $\mathrm{~S}$ \\
\hline Amino acid & $1.60 \mathrm{~g} / 100 \mathrm{~g}$ & $1.15 \mathrm{~g} / 100 \mathrm{~g}$ & $\mathrm{~S}$ \\
\hline Condensed tannins & $0.15 \mathrm{~g} / 100 \mathrm{~g}$ & $0.18 \mathrm{~g} / 100 \mathrm{~g}$ & $\mathrm{NS}$ \\
\hline
\end{tabular}

Table 2: Chemical properties of Nag Hamady 2 and Medjool date's fruits. 
Tannins condensed

The findings in table 2 indicated that there were no significantly different in fruit tannins. The results are consistent with [62], who showed that the tannin level of fruits varied between 0.10 and $0.37 \%$ in many Saudi and Iraqi cultivars. Samia [23] established that the content of tannins in a fruits was low in Sewy $(0.16 \%)$, high in Zahdi (0.20\%), and intermediate in the remaining cultivars. Amany., et al. [24] demonstrated that the chemical fruit qualities of the Madjool, Anbara, and Segae cultivars were found to be perfect, while the acidity and total soluble tannins were found to be the lowest.

\section{Composition of minerals}

The macro-elements ( $\mathrm{Na}, \mathrm{K}$, and $\mathrm{Ca}$ ) were determined utilizing a flame photometer table 3 . All the other constituents $(\mathrm{Cu}, \mathrm{Fe}, \mathrm{Mg}$, Mn, Zn, and P) had been evaluated by using an atomic absorption spectrophotometer. The percentage of all examined components in Nag Hamady 2 is shown in table 3 in comparison to the composition of the same minerals in Medjool cv. supplying important and beneficial materials. The great calcium content suggests that Nag Hamady 2 may be a good supply of calcium, which is required for healthy bone formation and energy metabolism, whereas the great potassium content in Medjool due to adding of potassiumcontaining fertilizers may be a factor. Though on the other hand, the potassium and sodium levels are rather low in Nag Hamady 2 is appropriate for hypertensive patients. Regardless of the fact that the palm was grown on unfertilized soil irrigated; its $\mathrm{Zn}$ and $\mathrm{Cu}$ contents were much greater than in cv. Medjool. On the other hand, were significantly increased in the content of $\mathrm{Mg}$ and $\mathrm{P}$ of Medjool cv. compared to Nag Hamady 2, which might possibly be related to the usage of fertilizers.

The mineral composition of date fruits Nag Hamady 2 were actually nearly same to the values reported by [40], cleared that it has been nine minerals found in the fleshes $(\mathrm{K}, \mathrm{Ca}, \mathrm{Mg}, \mathrm{Fe}, \mathrm{Cu}, \mathrm{Zn}$, $\mathrm{Mn}$, and $\mathrm{Na}$ ). Potassium was the most prevalent element, followed by magnesium and calcium, in all the fruit flesh types tested, with substantial varietal variations for almost all elements. These date fruits are high in minerals, mg/100g of an element (dw) 545.88 K, Calcium 76.15\%, phosphorus 70.50\% and Magnesium 57.70\%. Macro-elements, there are 38.41 Sodium, $6.27 \mathrm{Fe}, 1.06 \mathrm{Cu}$, and 1.77
Mn. Micro-elements, there are 1.02 gm of Zinc (Zn). Saidy date fruits had $6.27 \mathrm{mg} / 100 \mathrm{~g}$ of dry weight iron as the most common microelement. $\mathrm{Cu}, \mathrm{Mn}$, and $\mathrm{Zn}$ concentrations in Saidy date fruits were $1.06,1.77$, and $1.02 \mathrm{mg} / 100 \mathrm{~g} \mathrm{dw}$, respectively [53]. From 8.8 $\mathrm{mg} / \mathrm{kg}$ to $24.4 \mathrm{mg} / \mathrm{kg}$, iron was the most prevalent trace metal in the fruits flesh. Trace element concentrations found to be similar to those reported in the flesh [63].

The date fruits often contain high levels of micronutrients, include $\mathrm{K}, \mathrm{P}, \mathrm{Mg}, \mathrm{Ca}, \mathrm{Na}$ and $\mathrm{Fe}$ concentrations in the analyzed date variations. The research found a strong correlation between potassium and date varieties. The potassium, phosphorus, magnesium, calcium, and sodium content of the date selections varied from 281.74 (Bumaan)-478.29 (Lulu) to 48.36 (Dabbas)-77.94 (Raziz) to 42.17 (Dabbas)-70.38 (Barhe) to 15.46 (Bumaan)-42.39 (Bumaan)-42.39 (Bumaan)-42 (Barhe). The iron content of all date varieties was good, with Raziz having the greatest concentration (1.51 mg/100g FW) and Dabbas having the lowest $(0.78 \mathrm{mg} / 100 \mathrm{~g}$ FW). Other date species have greater levels of K (444.69 mg/100g), $\mathrm{P}$ (65.84 mg/100g), Mg (70.38 mg/100g) and Ca (42.39 mg/100g) than Barhee dates [36]. In general, potassium and phosphorous elements stimulate the regeneration of human cells, while magnesium and calcium are essential for the creation of a healthy bone mass. As a result, date fruits are regarded to be a healthy diet rich in minerals and play an important function in the development of the immune system for humans because of the presence of these key components in the fruit. It has been scientifically shown and verified that minerals are beneficial to human health. Bone and tooth health, the neurological system, blood control, red blood cell generation, as well as many other activities are all dependent on mineral intake [64]. Dates have been extensively studied for their mineral content in the past, and the results have consistently shown that dates are an excellent source of these nutrients.

Although no horticultural interventions were performed on the palm tree under assessment, the iron ( $\mathrm{Fe}$ ) concentration was considerably 8-fold greater in Nag Hamady 2 than in Medjool cv. These discrepancies in mineral composition between date fruit Nag Hamady 2 and Medjool cv. might be explained by their genetic origin, location, soil moisture content, mineral nutrient availability, and differences in organic matter content. 


\begin{tabular}{|l|c|c|c|}
\hline Minerals & Nag Hamady 2 & Medjool & Significantly \\
\hline Calcium, $\mathrm{Ca}$ & 62.8 & $61.00 \mathrm{mg}$ & $\mathrm{S}$ \\
\hline Copper, $\mathrm{Cu}$ & 0.53 & 0.42 & $\mathrm{~S}$ \\
\hline Iron, $\mathrm{Fe}$ & 8.80 & 0.17 & $\mathrm{~S}$ \\
\hline Magnesium, Mg & 12.67 & 48.30 & $\mathrm{~S}$ \\
\hline Manganese, Mn & 0.70 & 0.50 & $\mathrm{NS}$ \\
\hline Phosphorus, $\mathrm{P}$ & 0.16 & 49.30 & $\mathrm{~S}$ \\
\hline Potassium, K & 0.55 & 652.00 & $\mathrm{~S}$ \\
\hline Sodium, Na & 0.18 & 1.40 & $\mathrm{~S}$ \\
\hline Zinc, Zn & 0.80 & 0.50 & $\mathrm{~S}$ \\
\hline
\end{tabular}

5. Vishwakarma RK., et al. "Physical properties of guar seeds". Food Bioprocess Technology 5.4 (2012): 1364-1371.

6. Ahmed AA., et al. "Mathematical model for some physical characteristics of smany and zaghloul date fruit varieties". International Agricultural Engineering Journal 21.3 (2019): 234-241.

7. Cunningham J and Sobolewski R. "Food composition databases for nutrition labelling: Experience from Australia". Journal of Food Composition and Analysis 24.4-5 (2011): 682-685.

8. Shaba EY., et al. "Nutritional and anti-nutritional composition of date palm (Phoenix dactylifera L.) fruits sold in major markets of Minna Niger State, Nigeria". African Journal of Pure and Applied Chemistry 9 (2015): 167-174. date flesh (mg/100g dry weight).

\section{Conclusion}

The date palm fruits are good because they include a variety of nutrients such carbs (especially soluble sugars), proteins, fats, and minerals. Because of the polyphenols and dietary fiber they contain, they're good for the digestive tracts.

New strain Nag Hamady 2 was compared to Medjool cultivar in terms of morphology and chemical compositions. The statistics clearly suggest that Nag Hamady 2 has tolerance characteristics. Because of its high content of carbs, protein, fiber, and important minerals like as potassium, calcium, and iron although it grows in poor soil with no irrigation and fertilization for this palm. This fruits also contains a high percentage of reducing sugars with no non-reducing sugars, so these fruits are useful for diabetics. The new strain Nag Hamady 2 is recommended for human consumption.

\section{Bibliography}

1. Kamal-Eldin A., et al. "Processing and Utilization of Palm Date Fruits for Edible Applications". Recent Patents on Food, Nutrition and Agriculture 4.1 (2012): 78-86.

2. Dillard CJ and German JB. "Phytochemicals: nutraceuticals and human health". Journal of the Science of Food and Agriculture 80 (2000): 1744-1756.

3. Safi E B., et al. "Common date palm in Tunisia: chemical composition of pulp and pits". International Journal of Food Science and Technology 43 (2008): 2033-2037.

4. Mohammed AA. "Palm culture and production of dates In Sudan". A country report, Palm and Dates Research Centre, Sudan (2000).

9. AOAC. "Official Methods of Analysis of Association Official Agricultural Chemists, (12th Ed.). Washington, DC” (1975).

10. Ismail B., et al. "Physico-chemical characteristics and total quality of five date varieties grown in the United Arab Emirates". International Journal of Food Science and Technology 41 (2006): 919-926.

11. Crisan EV and Sands A. "Nutrition value in: Biology and cultivation of Edibles Mushrooms, Eds., Chang, S. T. and W. A. Hayes". New York, Academic Press (1978): 137-168.

12. Singh RP., et al. "Studies on the Antioxidant Activity of Pomegranate (Punica granatum) Peel and Seed Extracts Using In vitro Models". Journal of Agricultural and Food Chemistry 50.1 (2002): 81-86.

13. Laurey S. "Protein structure core facility, Omaha, NE, 68 (1997): 198-4525.

14. AOAC. "Association of Official Agricultural Chemists". Official Methods of Analysis. 15 Ed. Published by A.O.A.C. Washington, D.C., USA.

15. Heckman M. “Collaborative study of a copper in feeds by atomic absorption spectrophotometry". Journal - Association of Official Analytical Chemists 54 (1971): 666-668.

16. Al-Barnawi HM. "Nutritional Composition of Protein Extract from Date Palm Fruit (Phoenix dactylifera L.) Cultivar Grown in Saudi Arabia". SciFed Journal of Protein Science 1.1 (2018): 20-33.

17. MSTAT Development Team. “MSTAT user's guide: a microcomputer program for the design management and analysis of agronomic research experiments". Michigan State University, East Lansing, USA (1989). 
18. Said A., et al. "Dates Quality Assessment of the Main Date Palm Cultivars Grown in Algeria". Annual Research and Review in Biology 4.3 (2014): 487-499.

19. Saeed IK and Yousof DE. "Nutritional changes in date fruits Barakawi cv. infested by date palm dust mite Oligonychus afrasiaticus Meg. measured by physical and chemical parameters". Persian Gulf Crop Protection 3.1 (2014): 46-51.

20. Sakr MM., et al. "Identification of some date palm (Phoenix dactylifera) cultivars by fruit characters". Indian Journal Science Technology 3.3 (2010): 338-342.

21. Abdul-Hamida NA., et al. "Quality evaluation of the physical properties, phytochemicals, biological activities and proximate analysis of nine Saudi date palm fruit varieties". Journal of the Saudi Society of Agricultural Sciences 19 (2020): 151160.

22. Afiq MA., et al. "Date seed and date seed oil". International Food Research Journal 20.5 (2013): 2035-2043.

23. Samia MH. "Comparative Study of Some Semi-Dry Arabian Date Palm Cultivars Grown in Mounofia Governorate". Egypt Journal of Agricultural Research 94.4 (2016): 859-873.

24. Amany MH., et al. "Economic and Numerical Evaluation of Some Date Palm Cultivars Grown in El-Wadi El-Jadid Governorate". Journal of Horticultural Science \& Ornamental Plants 12.2 (2020): 136-142.

25. Iqbal M., et al. "Physio-chemical characteristics of date palm (Phoenix dactylifera L.) cultivars at various maturity stages under environmental conditions of Dera Ismail khan". Journal of Agricultural Research 49.2 (2011): 249-261.

26. Osman SM. "Fruit quality and general evaluation of Zaghloul and Samany date palms cultivars grown under conditions of Aswan". American Eurasian. Journal of Agriculture and Environmental Sciences 4.2 (2008): 230-236.

27. Ragab WS., et al. "Physical and Chemical Changes in Fruits of Three Dates Palm (Phoenix dactylifera L.) Grown in South Valley, EGYPT". Journal of Food and Dairy Sciences Mansoura Univ 2.11 (2011): 605 - 615.

28. Gado GBA. "Chemical and technological studies on some local date varieties". MSc. Thesis, The Faculty of Agricultural and Food Sciences Minia. Univ. Egypt (1999).

29. Alahyane A., et al. "Bioactive compounds and antioxidant activity of seventeen Moroccan date varieties and clones (Phoe- nix dactylifera L.)". South African Journal of Botany 121 (2019): 402-409.

30. El-Nakhal HM., et al. "Tamrheeb new protein rich product from dates". Lebensmittel Wissenschaft und - Technologie 21.3 (1988): 172-175.

31. Parvin S., et al. "Nutritional Analysis of Date Fruits (Phoenix dactylifera L.) in Perspective of Bangladesh". American Journal of Life Sciences 3.4 (2015): 274-278.

32. Al-Mamary M., et al. "The in vitro antioxidant activity of different types of palm dates (Phoenix dactylifera) syrups". Arabian Journal of Chemistry 7 (2014): 964-971.

33. Nehdi I., et al. "Characteristics and chemical composition of date palm (Phoenix canariensis) seeds and seed oil". Industrial Crops and Products 32.3 (2010): 360-365.

34. Gadalla EG. "Behavior study of some Arabian Date Palm Cultivars Produced through Tissue Culture grown under Al Saff region - Giza Governorate". Egyptian Journal of Applied Science 28.8 (2013): 436-453.

35. Rastegar S., et al. "Enzyme activity and biochemical changes of three date palm cultivars with different softening pattern during ripening". Food Chemistry 134.3 (2012): 1279-1286.

36. Rambabu K., et al. "Nutritional Quality and Physico-Chemical Characteristics of Selected Date Fruit Varieties of the United Arab Emirates". Processes 8.256 (2020): 1-11.

37. El-Sohaimy SA and Hafez EE. "Biochemical and nutritional characterizations of date palm fruits (Phoenix dactylifera L.)". Journal of Applied Sciences Research 6.8 (2010): 1060-1067.

38. Amen A., et al. "Evaluation of Sewy Date Palm Productivity under Different Climatic Conditions". Assiut Journal of Agricultural Sciences 49.1 (2018): 69-78.

39. Souli I., et al. "Nutritional values and antioxidant activities of juice extracted from some Tunisian date varieties". Journal of New Sciences 35.6 (2016): 1976-1985.

40. Vinita and Darshan P. "Nutritional composition of fruit of four date palm (Phoenix dactylifera L.) cultivars grown in Haryana, India". Asian Journal of Dairy and Food Research 35.4 (2016): 331-334. 
41. Sadiq I., et al. "The nutritional evaluation and medicinal value of date palm (Phoenix dactylifera)". International Journal of Modern Chemistry 4 (2013): 147-154.

42. Rawah BE. "Physico-chemical characteristics of some Sudanese date cultivars as affected by traditional storage methods". A dissertation submitted to the University of Khartoum partial fulfillment of requirement of the degree of Master of Science in food science and technology (2007).

43. Nadeem M., et al. "Quality evaluation of some Pakistani Date Varieties". The Pakistan Journal of Agricultural Sciences 48 (2001): 305-313.

44. Al-Farsi MA and Lee CY. "Nutritional and functional properties of dates: A review". Critical Reviews in Food Science and Nutrition 48 (2008): 877-887.

45. Haseeb GMM., et al. "Evaluation of Some Date Palm Seeded Trees Grown under El-Frafra Oasis Conditions". Journal of Horticultural Science and Ornamental Plants 6.3 (2014): 161-169.

46. Metwaly HA., et al. "Evaluation of some seeded date palm trees grown in Fayoum governorate". A. Physical characteristics. $4^{\text {th }}$ Conference on Recent Technologies in Agriculture (2009): 684-699.

47. Salama ASM., et al. "Effect of magnesium fertilizer sources and rates on yield and fruit quality of date palm cv. Hayany under Ras-Sudr conditions". Journal of Agriculture and Biological Sciences 10.2 (2014): 118-126.

48. Ramadan BR. "Biochemical, nutritional and technological studies on dates". Ph.D. Thesis, Faculty of Agriculture - Assiut University, Egypt (1995).

49. Khan MN., et al. "Physico-chemical characterization of date varieties using multivariate analysis of plums". Food Chemistry 81 (2008): 321-326.

50. Borchani C., et al. "Chemical properties of 11 date cultivars and their corresponding fiber extracts". African Journal of Biotechnology 9.26 (2010): 4096-4105.

51. Liu S., et al. "A prospective study of dietary glycemic load, carbohydrate intake and risk of coronary heart disease in US women". The American Journal of Clinical Nutrition 71 (2000): 1455-1461.
52. Gromski PS., et al. "A tutorial review: Metabolomics and partial least squares-discriminant analysis- a marriage of convenience or a short gun marriage". Analytica Chimica Acta 879 (2015): 10-23.

53. Ramadan BR., et al. "Effect of some Treatments on Chemical Composition and Quality Properties of Saidy Date Fruit (Phoenix dactylifera L.) During Storage". Assiut Journal of Agricultural Sciences 47.5 (2016): 107-124.

54. Shahdadi F., et al. "Study of phenolic compound and antioxidant activity of date fruit as a function of ripening stages and drying process". Journal of Food Science and Technology 52.3 (2015): 1814-1819.

55. Kchaou W., et al. "Effects of extraction solvents on phenolic contents and antioxidant activities of Tunisian date varieties (Phoenix dactylifera L.)". Industrial Crops and Products 45 (2013): 262-269.

56. Wu X., et al. "Lipophilic and hydrophilic antioxidant capacities of common foods in the United States". Journal of Agricultural and Food Chemistry 52 (2004): 4026-4037.

57. Louaileche H., et al. "Total Phenolic, Flavonoid Contents and in Vitro Antioxidant Activity of Algerian Date Palm Varieties: A Comparative Study". American Journal of Food Science and Health 1.3 (2015): 63-68.

58. Benmeziane-Derradji F. "Nutritional value, phytochemical composition, and biological activities of Middle Eastern and North African date fruit: an overview". Euro-Mediterranean Journal for Environmental Integration 41 (2019): 39.

59. Lima GPP., et al. "Polyphenols in fruits and vegetables and its effect on human health". Food and Nutrition Sciences 5.11 (2014): 1065-1082.

60. Ishurd O., et al. "Protein and amino acids contents of Libyan dates at three stages of development". Journal of the Science of Food and Agriculture 84 (2004): 481-484.

61. Zhang CR., et al. "Health-benefits of date fruits produced in Saudi Arabia based on in vitro antioxidant, anti-inflammatory and human tumor cell proliferation inhibitory assays". Journal of the Saudi Society of Agricultural Sciences 16 (2017): 287293.

62. Sayed SM. "Evaluation of some date palm cultivars grown under El-Minia region condition M. Sc. Thesis Fac. Agric. El-Minia Univ (1999). 
63. Al Juhaimi F., et al. "Physico-chemical properties and mineral contents of seven different date fruit (Phoenix dactylifera L.) varieties growing from Saudi Arabia". Environmental Monitoring and Assessment 186.4 (2014): 2165-2170.

\section{Assets from publication with us}

- Prompt Acknowledgement after receiving the article

- Thorough Double blinded peer review

- Rapid Publication

- Issue of Publication Certificate

- High visibility of your Published work

Website: www.actascientific.com/

Submit Article: www.actascientific.com/submission.php

Email us: editor@actascientific.com

Contact us: +919182824667 